\title{
Alzheimer's Gone Viral: Could Herpes Simplex Virus Type-1 Be Stealing Your Memories?
}

Rhutuja Khokale $^{1}$, Ayesha Kang ${ }^{2}$, Keri-Ann R. Buchanan-Peart ${ }^{2}$, Maxine L. Nelson ${ }^{2}$, Oluwatayo J. Awolumate $^{2}$, Ivan Cancarevic ${ }^{2}$

1. Neurology, California Institute of Behavioral Neurosciences \& Psychology, Fairfield, USA 2. Internal Medicine, California Institute of Behavioral Neurosciences \& Psychology, Fairfield, USA

Corresponding author: Rhutuja Khokale, dr.rhutuja@gmail.com

\begin{abstract}
Alzheimer's disease $(\mathrm{AD})$ is one of the principal causes of disability and morbidity. It is one of the most expensive illnesses. Despite this, there are no significant data regarding its etiology and optimal treatment. This review concentrates on the viral hypothesis of AD. After a comprehensive PubMed literature search, we analyzed the studies associating herpes simplex virus type-1 (HSV1) infection to AD from the previous 10 years. Molecular mechanisms whereby HSV1 induces AD-related pathophysiology, including neuronal production and accumulation of amyloid-beta (amyloid- $\beta$ ), abnormal phosphorylation of tau proteins, impaired calcium homeostasis, and autophagy, are addressed. The virus also imitates the disease in other ways, showing increased neuroinflammation, oxidative stress, synaptic dysfunction, and neuronal apoptosis. Serological studies correlate HSV1 infection with AD and cognitive impairment. A causal link between HSV1 and $\mathrm{AD}$ raises the concept of a simple, efficient, and preventive treatment alternative. Anti-viral agents impede brain degeneration by preventing HSV1 spread and its replication, decreasing hyperphosphorylated tau and amyloid- $\beta$; thus providing an efficacious treatment for AD. We also mention brown algae, intravenous immunoglobulin (IVIG), and a synthetic drug, BAY57-1293, with anti-viral properties, as options for treating $\mathrm{AD}$. We want to recommend future researchers to look for more affordable, noninvasive, and swifter techniques to identify HSV1 in the brain and assist in the early detection and prevention of $\mathrm{AD}$.
\end{abstract}

Received 09/22/2020

Review began 10/11/2020 Review ended 11/17/2020 Published 11/27/2020

(c) Copyright 2020 Khokale et al. This is an open access article distributed under the terms of the Creative Commons Attribution License CC-BY 4.0., which permits unrestricted use, distribution, and reproduction in any medium, provided the original author and source are credited.
Categories: Internal Medicine, Neurology, Infectious Disease

Keywords: alzheimer's disease and herpes simplex virus type 1, herpes simplex and alzheimer's disease, antiviral agents and alzheimer's disease, alzheimer's disease, alzheimer's disease/virology, alzheimer's disease and hsv1

\section{Introduction And Background}

"Alzheimer's disease locks all the doors and exits. There is no reprieve, no escape."

-Patricia Reagen Davis.

The dominant subtype of senile dementia in the world is Alzheimer's disease (AD) [1-6]. In 2015, it accounted for 18-20 million cases globally [7-8]. In 2014, the United States (US) accounted for approximately five million cases, and epidemiologists expect a rise to nearly 14 million by 2060 [9]. Among the elderly, it is the sixth leading cause of death in the US [9]. The median annual total expenditure for one patient having advanced $\mathrm{AD}$ is estimated to be more than $\$ 50,000$ [10]. By 2040, the cost of treating $\mathrm{AD}$ is expected to rise from around $\$ 215$ billion to more than $\$ 500$ billion annually [9]. The economic burden of AD in the US rounds up to $1.09 \%$ of global GDP [3]. Data have shown an expenditure of \$604 billion worldwide in 2010 $[8,11]$.

$\mathrm{AD}$ is a progressive neurodegenerative disorder of multifactorial etiology, causing irreversible pathological changes in the brain [4,7,11-16]. Macroscopically, this appears as atrophy of the brain starting from the locus coeruleus, entorhinal cortex, and hippocampus of medial temporal lobes and gradually affecting the inferolateral temporal cortex and nucleus basalis of Meynert [2,10-11]. Microscopically, the changes are seen as amyloid plaques (extracellular), neurofibrillary tangles (NFTs), and neuropil threads (intracellular) [2-3,58,10-11,14-15,17-19]. These are the characteristic pathological hallmarks of AD [2-3,5-8,11,15,17-19]. Neuritic/senile amyloid plaques are composed of amyloid- $\beta$ protein obtained due to the proteolysis of amyloid- $\beta$ precursor protein (APP) $[2-3,7,10,16,19]$. APP is a transmembrane protein involved in neurite growth, synaptogenesis, and transmembrane signal transduction $[11,19]$. NFTs are made up of abnormally hyperphosphorylated tau protein and reside inside the nerve cell bodies, whereas neuropil threads lie within dendritic processes $[2-3,7-8,11,14]$. Tau is a neuronal stabilizing microtubule-associated protein and becomes pathological solely in its hyperphosphorylated form [7-8,10,19]. Other pathologies seen in AD include neuroinflammation, degeneration of neurons, and loss of synapses [2,14]. Most of these pathological changes appear well before any symptoms are noticed $[18,20]$. In approximately $80 \%$ of the patients, the cognitive changes follow a predictable path, starting with memory impairment to verbal and visuospatial 
deficits, ultimately leading to executive dysfunction $[2,10,15]$. Additional symptoms include behavioral abnormalities, intellectual impairment, and progressively deteriorating cognitive function leading to dementia $[2,4,11,14-15]$. Symptoms gradually worsen, and ultimately, the ability to communicate and perform daily living activities is severely impaired, resulting in a loss of independence $[2,10,15]$. The initiation and progression of $\mathrm{AD}$ appear to be affected by genetic predisposition and a myriad of environmental and lifestyle factors [7].

Early-onset $\mathrm{AD}$ (EOAD) and late-onset $\mathrm{AD}$ (LOAD) are two classified forms of $\mathrm{AD}[2,15]$. EOAD presents in patients below $60-65$ years and comprises approximately $1 \%-6 \%$ of all AD cases $[2,15]$. Autosomal dominant genetic mutations in either APP, PSEN1 (presenilin1), or PSEN2 (presenilin2) genes links to EOAD, all of which affect the breakdown of APP and leads to the formation of amyloid- $\beta$ plaques, a trait of AD $[2,10,15,18]$. LOAD accounts for the majority of AD cases (approximately $95 \%$ ) and usually occurs after 60-65 years $[2,15]$. The exact etiology of LOAD is unknown, but certain risk factors have been identified $[2,15,19]$. The genetic risk factor of utmost importance for $\mathrm{AD}$ is the apolipoprotein-E epsilon4 allele (APOE- 4 ) $[2,4,5$ $8,11,15,17,19-26]$. One allele doubles or triples the risk, whereas two alleles increase the risk by 16 manifolds [10]. Several other factors predisposing to the development of $\mathrm{AD}$ include traumatic brain injury, diabetes mellitus, hypertension, dyslipidemia, vascular infections, obesity, physical inactivity, and smoking $[2,10,15,21]$. Lower socioeconomic status, poverty, minority status (African-American and Hispanic ethnicity in the US), and lower educational attainment are other potential risk factors [2]. Presently, there is no reliable cure for $\mathrm{AD}[5,7-8,10,17,27]$. Treatment options for $\mathrm{AD}$ include cholinesterase inhibitors and memantine $[10,17]$. Cholinesterase inhibitors like donepezil, galantamine, and rivastigmine act to increase acetylcholine availability at synapses for better communicability amongst neurons $[10,28]$. These drugs have limited efficacy and do not alter the course of the disease [17]. Many recent studies/trials have failed to provide an effective cure for AD, including anti-amyloid treatments like solanezumab [17-18]. Current treatments for $\mathrm{AD}$ are merely palliative, and thus there is an urgent need for medications that delay disease progression [27].

Herpes simplex virus type-1 (HSV1) is a highly neurotropic, double-stranded deoxyribonucleic acid (DNA) virus $[2-4,7,11,14-17,19,21,25,29-31]$. It is a ubiquitous pathogen that affects $80 \%-90 \%$ of the US population by the sixth decade, with persisting serum antibodies [2-3,7,11,14,17,24]. It primarily infects the oral, corneal, and dermal epithelium causing vesicular lesions $[4,11,14-15]$. It can escape the immune system and become dormant in the sensory ganglion $[4,7,15,19,21,24,30]$. The trigeminal ganglion is the primary reservoir for HSV1 during dormancy $[2,7,11,15-17,20,24]$. More than $90 \%$ of US adults have HSV1 DNA in their trigeminal ganglion [20]. It can establish a lifelong infection and spread readily among humans $[2,15,17]$. Prolonged latent periods and episodic recrudescence characterize HSV1 infection [2,15-16]. Upon reactivation, the virus can travel through the sensory ganglia back to the epithelium and cause herpes labialis, commonly known as cold sores [2,4,7-8,11,15-17,22]. In approximately $25 \%$ of individuals infected with HSV1, the virus reactivates and migrates to the brain, causing herpes simplex encephalitis (HSE) [4,11,17,21,29-30]. HSE is the most prevailing form of sporadic viral encephalitis [2,14,21,32-33]. Surprisingly, the APOE- $\varepsilon 4$ genotype is a risk factor for HSV1 infection (cold sores) $[5,8,11,14,17,24,27,32-33]$.

This review examines evidence suggesting HSV1 as a causative agent of AD. We studied the literature focusing on viral characteristics of HSV1, the mechanisms this virus uses to enter the brain and cause neuropathological changes, potential treatment alternatives, and the genetic background of AD. We used PubMed to identify relevant papers using the keywords: ("Herpes Simplex"[Mesh]) AND "Alzheimer Disease" [Mesh], ("Antiviral Agents"[Mesh]) AND "Alzheimer Disease"[Mesh], ("Alzheimer Disease/virology"[Mesh], Alzheimer's disease and herpes simplex virus type-1. We included the studies published within the last 10 years.

\section{Review}

\section{The entry of herpes simplex virus type-1 into the brain}

Aging is the principal risk factor for $\mathrm{AD}$ [11]. Cell-mediated immune response by CD8+ T lymphocytes and interferon-gamma inhibits viral reactivation from latency [15]. Immunosenescence affects this response, making the brain vulnerable to infectious agents [14-15]. HSV1 has been proposed as a potential risk factor in the development of AD $[1-4,8,11,13-14,17-19,21,24-25,29,31,33-39]$. A meta-analysis by Steel et al. concluded that there is an increased risk for AD when HSV1 is present in the brain compared to controls (OR 1.38; 95\% CI 1.14-1.66) [35]. The numerous factors mentioned in Table 1 trigger viral reactivation from latency. 


\section{Cureus}

\begin{tabular}{|c|c|c|c|}
\hline Sr. No. & Causes of viral reactivation & Author (Reference) & Year of Publication \\
\hline \multirow{3}{*}{1.} & \multirow{3}{*}{ Generalized/peripheral infection or inflammation. } & Harris et al. [7] & 2015 \\
\hline & & Itzhaki et al. $[8,22,32,33]$ & $2012,2014,2017,2018$ \\
\hline & & Wozniak et al. [27] & 2011 \\
\hline \multirow{4}{*}{2.} & \multirow{4}{*}{ Morbid state and immunosenescence. } & Harris et al. [15] & 2018 \\
\hline & & Mangold et al. [19] & 2019 \\
\hline & & Itzhaki et al. [32] & 2017 \\
\hline & & Eimer et al. [37] & 2018 \\
\hline \multirow{3}{*}{3.} & \multirow{3}{*}{ Impaired integrity of the blood-brain barrier (BBB). } & Devanand et al. [17] & 2018 \\
\hline & & Mangold et al. [19] & 2019 \\
\hline & & Eimer et al. [37] & 2018 \\
\hline \multirow{11}{*}{4.} & \multirow{11}{*}{ Stress and immunosuppression. } & Olsson et al. [5] & 2016 \\
\hline & & Harris et al. $[7,15]$ & 2015,2018 \\
\hline & & Piacentini et al. [11] & 2014 \\
\hline & & Devanand et al. [17] & 2018 \\
\hline & & Ball et al. [20] & 2012 \\
\hline & & Itzhaki et al. $[22,32,33]$ & $2014,2017,2018$ \\
\hline & & Tudorache et al. [23] & 2017 \\
\hline & & Lathe et al. [24] & 2019 \\
\hline & & Wozniak et al. [27] & 2011 \\
\hline & & Epstein et al. [36] & 2020 \\
\hline & & Rizzo et al. [40] & 2020 \\
\hline 5. & Head trauma. & Wozniak et al. [27] & 2011 \\
\hline
\end{tabular}

\section{TABLE 1: Risk factors responsible for activation of latent HSV1}

HSV1 - Herpes simplex virus type-1

Upon reactivation, the virus can follow an anterograde or retrograde path [2,17]. In retrograde fashion, there is axonal transport of HSV1 particles, which infiltrate the locus coeruleus progressing to the temporal lobe, particularly the hippocampus and entorhinal cortex [7,17,20]. Another mechanism is the intraneuronal flow of viral particles along the trigeminal nerve branches that supply basal meninges or the olfactory pathway $[14,20]$. Martin et al. also provided evidence of various envelope glycoproteins like $\mathrm{gD}, \mathrm{gB}$, and $\mathrm{gE}$ in the transsynaptic spread of viruses [14]. Thus, the virus can access synaptically linked neural circuits [14]. The dendritic nerve terminals of olfactory receptor neurons are exposed directly and, therefore, the macromolecules enter freely and transport across the synapses [17]. These olfactory receptors further synapse onto the olfactory bulb's mitral cell neurons, which project onto the entorhinal cortex, amygdala, and hippocampus [15]. Animal studies by Harris et al. demonstrated the use of this pathway by HSV1 [15]. They also identified viral DNA in olfactory bulb samples of the human brain using polymerase chain reaction (PCR) [15]. They found impaired olfactory function associated with increased incidents of mild cognitive impairment (MCI) and $\mathrm{AD}$ [15]. The study also found neurodegenerative pathology in the olfactory bulb and tract in early $\mathrm{AD}[15]$. Lastly, the virus spreads via the bloodstream due to the disruption of the blood-brain barrier (BBB) $[3-4,11,17,41]$. The upregulation of neuroinflammatory markers and early neurodegeneration accompanies viral reactivation [7]. Thus, recurrent HSV1 reactivation in the brain could lead to ADassociated neurodegenerative processes [32].

These studies demonstrate a relationship between HSV1 and AD. A physiological decline in the immune system is a common reason for infection by HSV1, which enters the brain to reactivate later and cause 
further damage. This literature can be explored further to identify the population at risk for HSV1-induced $\mathrm{AD}$ and encourage researchers to find a preventive measure.

\section{Pathological changes in the brain by herpes simplex virus type-1}

Neuroinflammation and Oxidative Stress

Microglia function as innate immune cells (resident macrophages), providing defense against pathogen invasion [15]. Upon HSV1 infection (Figure 1), the activated microglia release pro-inflammatory molecules, leading to increased formation of reactive oxygen species (ROS) and reactive nitrogen species (RNS) [7,15]. These reactive species cause oxidative damage, further promoting neurodegenerative processes [7]. An uncontrolled inflammation and amplified cytokine cycle induce neuronal injury, apoptosis, and chronic disease progression $[7,15]$.

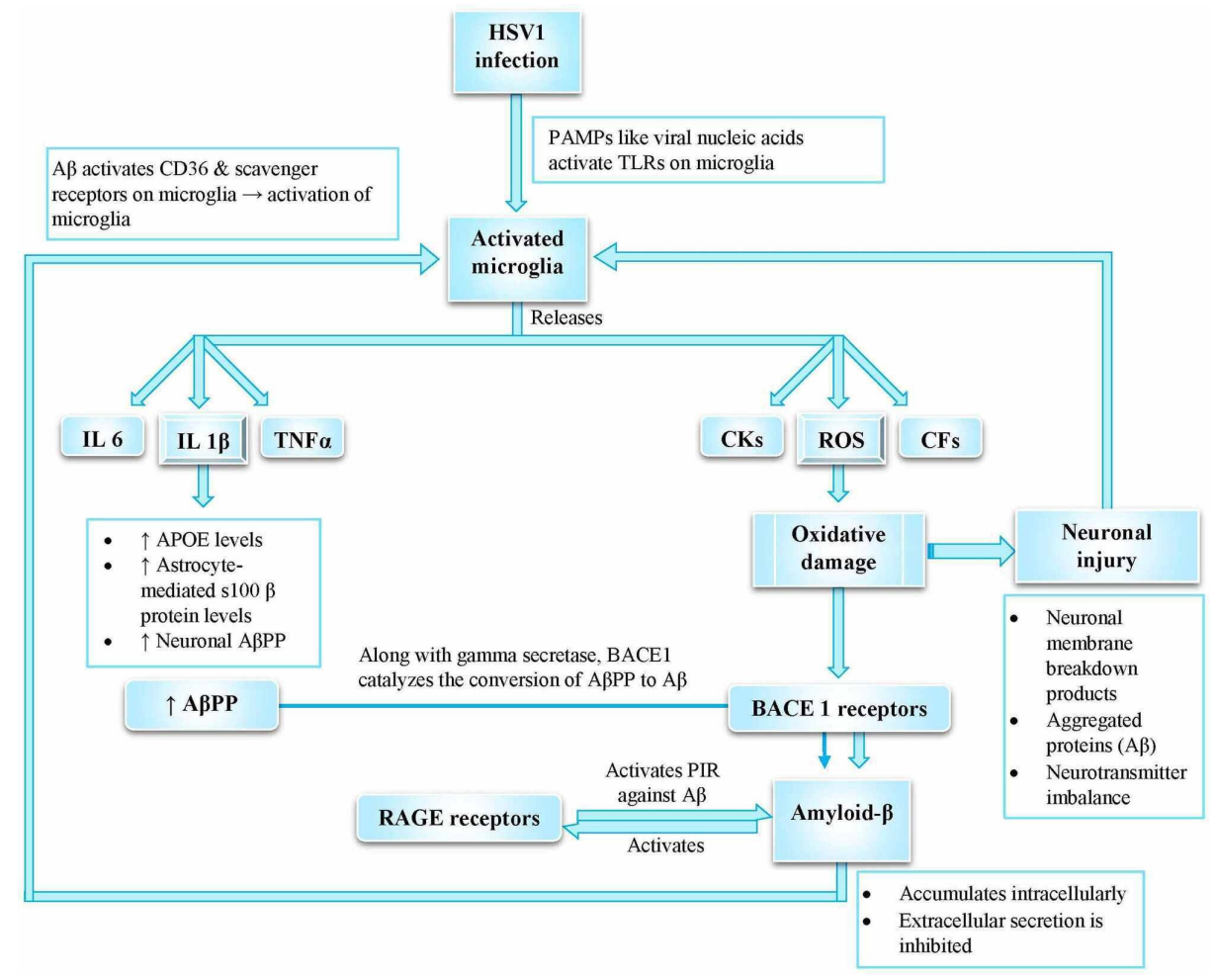

\section{FIGURE 1: Viral nucleic acids on HSV1 interact with TLRs on microglia, leading to microglial production of pro-inflammatory cytokines}

Studies support ROS as a mediator of neuroinflammation and AD pathogenesis. Interactions between HSV1 and oxidative stress promote neurodegenerative processes found in early AD.

Key: HSV1 - Herpes simplex virus type-1, TLRs - Toll-like receptors, PAMPs - Pathogen-associated molecular patterns, IL 6 - Interleukin6, TNFa - Tumor necrosis factor a, IL1 $\beta$ - Interleukin $1 \beta$, CKs Cytokines, CFs - Complement Factors, ROS - Reactive oxygen species, A $\beta P P$ - Amyloid $\beta$ precursor protein, BACE1 - Beta-site amyloid precursor protein cleaving enzyme1, RAGE - Receptor for advanced glycation end-products)

References: $[2,7,14-15,18,20,32,42]$

Neuronal injury, neuronal membrane breakdown products, cytosolic compounds, and glutamate excess further activate microglia [7]. Thus, overworked microglia damage the neurons [18,32]. This vicious cycle repeats itself to establish an inflammatory milieu [7,15]. HSV1, along with oxidative stress, potentiates the accumulation of intracellular amyloid- $\beta$ and inhibits its secretion to the extracellular medium [7,42]. Harris et al. concluded that interactions between cytokines and the brain after crossing the BBB is the likely mechanism of neuropathology and brain dysfunction [15].

Another aspect highlighted by Itzhaki et al. linking HSV1 to AD, is lysosomal impairment due to interactions between HSV1 infection and oxidative stress leading to the accumulation of toxic substances, further accelerating neurodegenerative changes (Figure 2) [33]. 


\section{Cureus}

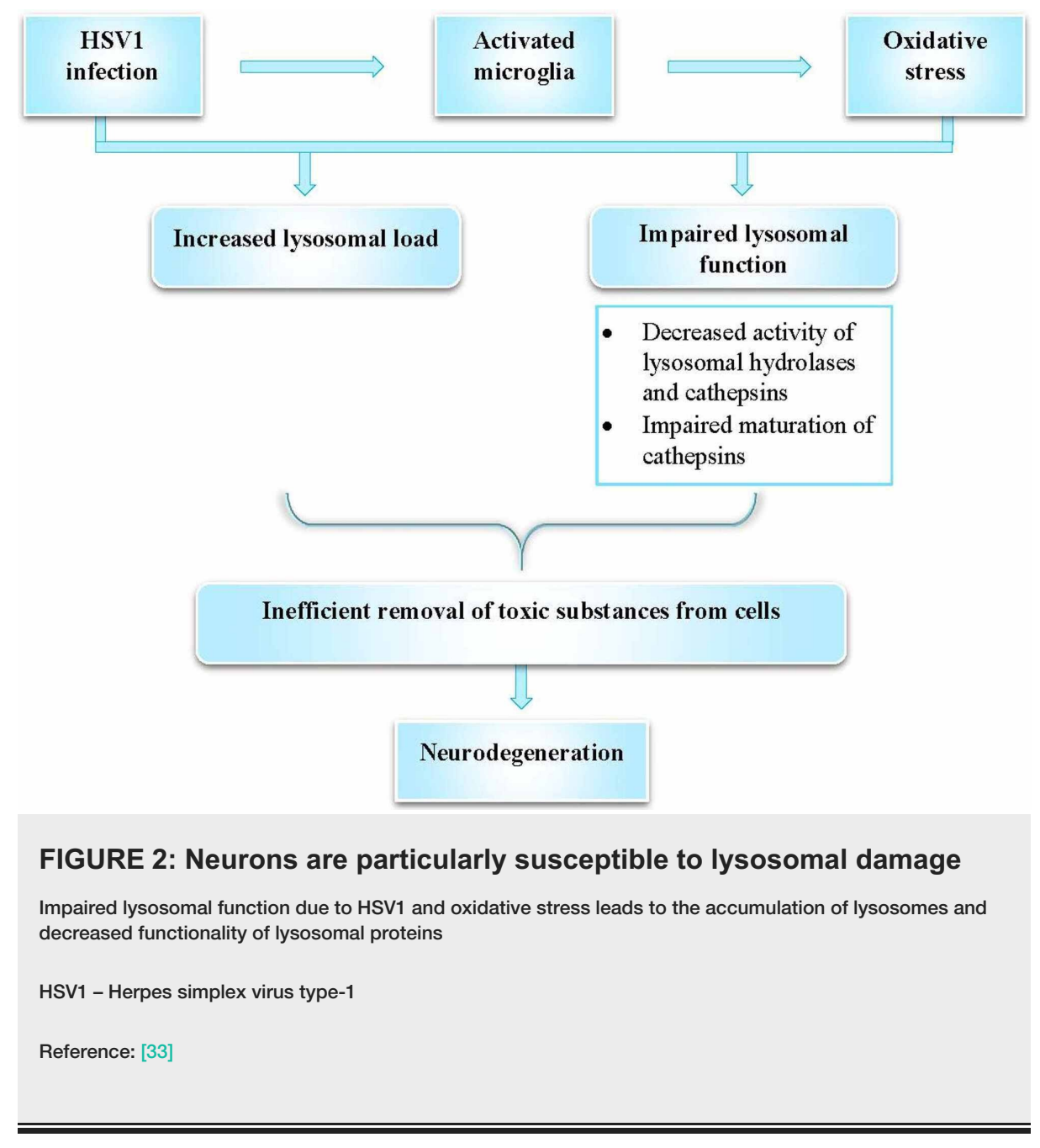

The above changes are known to occur early in AD development, thus supporting the role of HSV1 in AD [33].

APOE and phosphatidylinositol binding clathrin assembly protein (PICALM) are essential susceptibility genes in $\mathrm{AD}[7,33,43]$. These susceptibility genes are linked with the HSV life cycle and correlate to cellular entry, intracellular transport, and APP processing [7,43]. Some of these susceptibility genes can lead to abnormalities in autophagy [33]. HSV1 inhibits the homeostatic process involved in the turnover/elimination of cytoplasmic components, damaged organelles, and protein aggregates, thereby modulating the host autophagy $[4,15]$. This mechanism also contributes to the deposition of amyloid plaques within the brain $[4,15,42]$. Mawanda et al. state that severe, recurrent, or chronic systemic infections can permanently damage the central nervous system (CNS), ultimately manifesting as cognitive impairment or dementia [2].

\section{Neurofibrillary Tangles (NFTs)}

HSV1 induces glycogen synthase kinase 3-beta (GSK3-beta) and protein kinase-A (PK-A), enzymes that cause tau phosphorylation at several sites $[2,15,17,19,27,36]$. A study by Harris et al. on neuroblastoma cells and murine neuronal cultures infected by HSV1 demonstrates the same [7]. In vitro and animal studies by La Rosa et al. correlate with the above findings [30]. Research on mouse neuronal cultures infected with HSV1 by Mawanda et al. displayed abnormal microtubule dynamics, tau hyperphosphorylation (P-tau), and significant neurite damage, ultimately resulting in apoptosis [2]. Harris et al. and Santana et al. suggest that HSV1 induces apoptosis using infected cell protein 34.5 (ICP 34.5), which dephosphorylates eukaryotic initiation factor $2 \alpha(\mathrm{eIF} 2 \alpha)$ to block both the shutdown of host cell protein synthesis and apoptosis $[15,42]$.

P-tau occurs in the activation pathway of the apoptotic process as a requirement for all changes at the cellular level that ends with the generation of apoptotic bodies [14]. They suggest that apoptotic processes and the neurodegeneration of the cytoskeleton are closely associated and occur due to various neurotoxic stimuli [14]. They found that HSV1 induces the hyperphosphorylation of Alzheimer-type tau epitopes, presenting a close analogy to the hyperphosphorylation processes described in neurodegenerative diseases [14]. Harris et al. and De Chiara et al. list the events after P-tau as conformational alterations forming paired 
helical filaments (PHFs) or NFTs, associated microtubule destabilization, synaptic damage, and neurodegeneration [15,29]. Viral kinases contribute to the occurrence of P-tau due to cross-species kinase promiscuity, whereby both human and viral kinases phosphorylate both human and viral proteins [17,20]. Another reason is the amino acid homology between human tau and HSV virus protein-22, the target of kinase UL13, which phosphorylates human tau [17,20].

\section{Amyloid Plaque}

The migration of new viral particles inside an infected cell requires interactions among HSV1 capsid proteins and APP $[4,8,17,22]$. Interaction between amyloid- $\beta$ and HSV1 protein gB leads to HSV1 infectivity impairment by preventing the virus from fusing with the plasma membrane [34,44]. In early HSV1 infection, amyloid- $\beta$ production plays a protective role in limiting it $[3,19,29,37,40,44]$. Following repeated viral reactivations, amyloid- $\beta$ production switches from being defensive to becoming neurotoxic $[19,29,32]$. Eimer et al. list the possible factors mediating this switch as pathogen virulence and persistence, host genetics, and environmental factors [37]. A $\beta$ peptide is overproduced to protect against latent HSV1 infection, leading to $\mathrm{AD}$ progression by contributing to amyloid plaque formation [2-3,34]. Overproduced $A \beta$ leads to synaptic dysfunction, causing cognitive impairment [38]. In HSV1 infected neurons, there is an A $\beta$ dependent reduction in the expression of the presynaptic proteins associated with the diminished synaptic transmission; Piacentini et al. have first documented this [38]. In a study by De Chiara et al. on cultured mouse cortical neurons, HSV1 induced A $\beta$ accumulation impaired synaptic function proving to be neurotoxic [29].

Studies on mice infected with HSV1 demonstrated that HSV1 reactivations triggered amyloid- $\beta$ aggregation [29]. This correlated with cognitive impairment in them [29]. A parallel investigation validated that the accumulation of $\mathrm{AD}$ hallmarks in the same mice's brain displayed impaired memory in behavioral tests [29]. These findings demonstrate that HSV1 infection of neuronal cells can generate multiple APP fragments with neurotoxic potentials (Figure 3) [29]. 


\section{Cureus}

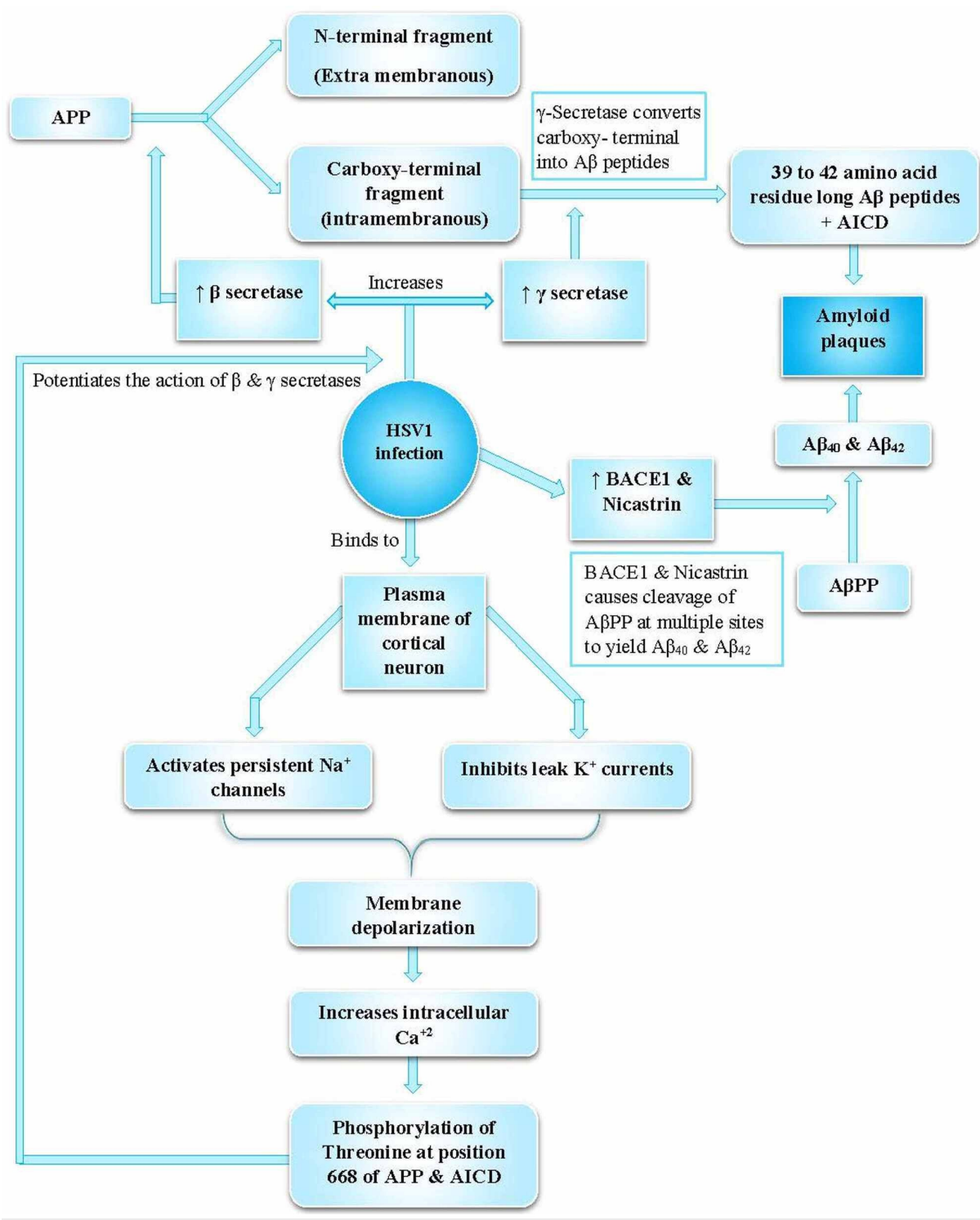

\section{FIGURE 3: HSV1 infection increases $\beta$ and $y$ secretase, which participate in the amyoidogenic pathway to ultimately form $A \beta$ peptides and AICD}

In the amyoidogenic pathway, $\alpha$ and $\beta$ secretases break down APP into $\mathrm{N}$ - and carboxy-terminal fragments. $A \beta 40$ and $A \beta 42$ primarily form the classical amyloid plaques seen in $A D$. The non-amyoidogenic pathway is made up of $a$ and $y$ secretase.

Key: HSV1 - Herpes simplex virus type-1, APP and ABPP - Amyloid-beta precursor protein, AICD - APP intracellular domain, BACE1 - Beta site APP cleaving enzyme

References: $[2,7,11,13,15-18,29,36,38,41]$

Makin et al. showed that the aggregation of amyloid- $\beta$ triggers a cascade of disease-causing events such as inflammation, NFT formation, synapse dysfunction, and cell death, leading to dementia [18]. Carter et al. state that AD susceptibility genes like APOE, apolipoprotein A1 (APOA1), clusterin, alpha 2-macroglobulin, insulysin, and caspase- 3 adhere to HSV1 and viral binding complement components, $\mathrm{C} 3$ and complement receptor-1 (CR1), which are involved in the clearance/degradation of amyloid- $\beta$ [43].

Harris et al. imply that amyloid plaque results from immunologic warfare between host and HSV1 [15].

Summary of Pathological Changes

The reactivated virus causes confined local damage via inflammatory and oxidative effects [15,32]. An 
increase in the intracellular levels of amyloid- $\beta$ and a decrease in APP and P-tau follow [4,17]. This further accelerates the deposition of amyloid plaques and NFTs, which are the main components of AD [13,17]. HSV1 infection induces early upstream events that eventually lead to A $\beta$ deposition and P-tau and thus superimpose our speculation that HSV1 is a possible risk factor for AD [39]. Pathogen-induced inflammation and CNS accumulation of amyloid- $\beta$ damage the BBB, contributing to the pathophysiology of AD [7]. Thus, a vicious cycle of uncontrolled neural inflammation and neurodegeneration ensues [7,11]. Thus, data show that reactivation of HSV1 infection causes AD [12-13,17,20-21,25,29,42,45].

Repeated cycles of HSV1 reactivation triggers chronic inflammation causing synaptic loss, leading to cognitive deficits. HSV1 infection induces upregulation in the expression of principal amyloid- $\beta$ processing components leading to its deposition in the brain. Over-production of amyloid- $\beta$ to contain HSV1, combined with decreased clearance of its aggregates due to aging, is neurotoxic and results in insoluble plaques. HSV1 infection increases the expression of enzymes involved in tau phosphorylation: GSK3 $\beta$ and PKA, resulting in tau hyperphosphorylation in infected neurons. This leads to neuronal cytoarchitectural changes, which affect synaptic stability and cognitive function. The above data demonstrate that it is, in fact, the reactivation of the virus that is responsible for the initiation of early $\mathrm{AD}$ changes.

\section{Epidemiological, genetic, and serological link between herpes simplex virus type-1 and Alzheimer's disease}

Detection of Herpes Simplex Virus Type-1 in the Brain

Several epidemiological studies (Table 2) identified HSV1 or HSV1 DNA or HSV1 proteins or HSV1 gene sequences in the brain of Alzheimer's patients and the elderly population at high risk of developing AD.
Sr.
No. Discovery
1. An autopsy study on brains of AD patients and healthy controls (elderly) found:
1a. In the AD group, $90 \%$ of amyloid plaques contained HSV1 DNA.
1b. In the AD group, $72 \%$ of HSV1 DNA was plaque-associated.
1c. The comparison group of healthy aged brains contained fewer plaques and in the control group, only $24 \%$ of HSV1 DNA was plaque-associated $(p<0.001)$.

Author

(Reference)

Year of Publication

Harris et al. [7]

2015

Devanand et

al. [17]

2018

In AD patients, $90 \%$ of amyloid- $\beta$ plaques were found to be co-localizing with HSV1 DNA.

\begin{tabular}{ll}
$\begin{array}{l}\text { Mawanda et al. } \\
\text { [2] }\end{array}$ & 2013 \\
Harris et al. [7] & 2015 \\
Itzhaki et al. & $2012,2014,2017,2018$ \\
[8,22,32,33] & \\
$\begin{array}{l}\text { Piacentini et al. } \\
\text { [11] }\end{array}$ & 2014 \\
$\begin{array}{l}\text { Devanand et } \\
\text { al. [17] }\end{array}$ & 2018 \\
$\begin{array}{l}\text { Mangold et al. } \\
\text { [19] }\end{array}$ & 2019 \\
$\begin{array}{l}\text { Ezzat et al. [21] } \\
\text { Limongi et al. }\end{array}$ & 2019 \\
[25] & 2016 \\
$\begin{array}{l}\text { Lopatko et al. } \\
\text { [26] }\end{array}$ & 2019 \\
$\begin{array}{l}\text { Wozniak et al. } \\
\text { [27,46] }\end{array}$ & 2011,2013 \\
\hline
\end{tabular}




\section{Cureus}

3. Latent HSV1 is present in a high proportion $(70-100 \%)$ of sporadic AD (using PCR).

Bourgade et al.

[34]

2014

Eimer et al. [37] 2018

Harris et al.

$[7,15]$

2015,2018

Itzhaki et al.

Harris et al. [7]

4. Presence of HSV1 DNA in human brains.

Itzhaki et al.

[22,33]

2014,2018

Agostini et al.

[3]

2016

Ball et al. [20]

2012

Limongi et al.

[25]

2016

5. Detection of
elderly brains.

Lopatko et al.

[26]

2019

Wozniak et al.

$[46,47]$

Harris et al. [7]

2015

6. HSV1 DNA in 67 out of 70 human brains of diagnosed Alzheimer's patients.

Ball et al. [20]

In situ hybridization of postmortem brain tissue samples from 21 patients with $A D$ and

7. 19 controls detected HSV1 DNA in a significantly higher proportion of AD samples $(81 \%)$ than controls $(47.4 \%)$.

Mawanda et al.

[2]

Mawanda et al.

[2]

Detection of latent HSV1 DNA in about $60 \%$ of brains of older adults, especially in the regions critically involved in $A D$.

Piacentini et al

[11]

Wozniak et al.

[27]

2011

Mawanda et al.

[2]

Harris et al.

[15]

9. Detection of HSV1 DNA in several brain regions, including the hippocampus, in AD patients, and the controls.

Lathe et al. [24] 2019

La Rosa et al.

[30]

2019

McManus et al.

[41]

Piacentini et al.

(Burgos et al.) 2014

[11]

Mawanda et al.

[2]

Itzhaki et al. [8]

2012

Harris et al.

[15]

2018

Wozniak et al. 


\section{Cureus}

\begin{tabular}{|c|c|c|c|}
\hline & & [27] & 2011 \\
\hline & & $\begin{array}{l}\text { La Rosa et al. } \\
\text { [30] }\end{array}$ & 2019 \\
\hline 12. & $\begin{array}{l}\text { Detection of HSV1 thymidine kinase gene sequences in a higher proportion of brain } \\
\text { tissue samples from AD cases (14/21) than controls (9/15) (using PCR). }\end{array}$ & $\begin{array}{l}\text { Mawanda et al. } \\
\text { [2] }\end{array}$ & 2013 \\
\hline 13. & $\begin{array}{l}\text { Detection of viral DNA sequences or viral antigens and intranuclear inclusion bodies } \\
\text { in astrocytes obtained from human brains who suffered from } A D \text {. }\end{array}$ & $\begin{array}{l}\text { Martin et al. } \\
{[14]}\end{array}$ & 2011 \\
\hline 14. & $\begin{array}{l}\text { Features of AD pathology are transmissible by inoculation in mice and primates by } \\
\text { HSV1. }\end{array}$ & $\begin{array}{l}\text { Devanand et } \\
\text { al. [17] }\end{array}$ & 2018 \\
\hline 15. & HSV1 DNA was identified in the trigeminal ganglion in $90 \%$ of clinical AD patients. & $\begin{array}{l}\text { Devanand et } \\
\text { al. [17] }\end{array}$ & 2018 \\
\hline 16. & $\begin{array}{l}\text { In a study, 8,362 subjects aged } 50 \text { years or over during the year } 2000 \text { who were newly } \\
\text { diagnosed with HSV1 were included. }\end{array}$ & $\begin{array}{l}\text { Itzhaki et al. } \\
\text { (Tzeng et al.) } \\
\text { [33] }\end{array}$ & 2018 \\
\hline 16a. & $\begin{array}{l}\text { The control group of } 25,086 \text { age and gender-matched subjects had no HSV infection } \\
\text { during the year } 2000 \text {. }\end{array}$ & & \\
\hline 16b. & $\begin{array}{l}\text { The frequency of dementia in the two groups was investigated during the } 10 \text { years: } \\
2001-2010 \text {. }\end{array}$ & & \\
\hline 16c. & $\begin{array}{l}\text { The risk of developing senile dementia in the HSV group was found to be } 2.56 \text {-fold } \\
\text { greater }(95 \% \mathrm{Cl} 2.351-2.795 ; \mathrm{P}<0.001) \text {. }\end{array}$ & & \\
\hline
\end{tabular}

TABLE 2: Studies demonstrating the presence of HSV1 DNA in the brain of elderly and AD patients

Key: HSV1 - Herpes simplex virus type-1, DNA - Deoxyribonucleic acid, AD - Alzheimer's disease, PCR - Polymerase chain reaction

HSV1 DNA is detected in the cerebrospinal fluid, suggesting that replication occurs in the CNS [11]. HSV1 receptors are abundantly expressed in the hippocampus [24].

Role of Apolipoprotein-E Epsilon-4 (APOE-ع4)

APOE has various isoforms encoded by the APOE gene on chromosome 19 [6-7,10-11,23,30]. One of these isoforms is APOE- $\varepsilon 4$, a well-established risk factor for AD, which when present in combination with HSV1 increases the risk for AD by 12 [2,7,10-11,14-15,17-19,22,26-27,29-30,32-33,35,41-42,46-47]. APOE plays a crucial role in the metabolism, circulation, and distribution of lipids [6-7,11,14,23]. APOE- $\varepsilon 4$ increases the susceptibility to infiltration of the brain by HSV1 [4,7,11,14-15,19,23-24]. It enhances the attachment and entry of HSV1 into the host cells $[2,7,41]$. It is also responsible for increased viral load in the brain and enhances amyloid- $\beta$ accumulation, thereby influencing plaque formation $[7,11,15,17,41]$. The risk for Alzheimer's disease increases when HSV1 is present in the brains of APOE- $\varepsilon 4$ carriers (OR 2.71) [35]. In almost $60 \%$ of cases, HSV1 plus APOE- $\varepsilon 4$ increases the risk for AD [8,33].

Association of Seropositivity and Cognitive Decline

HSV1 reactivation, measured by anti-HSV1 immunoglobulin M (IgM) antibodies, is associated with an increased risk of developing $\mathrm{AD}$ (Table 3) [3,7,13-17,20-22,25,29,42,48]. 


\section{Cureus}

\begin{tabular}{|c|c|c|c|}
\hline $\begin{array}{l}\text { Sr. } \\
\text { No. }\end{array}$ & Study & $\begin{array}{l}\text { Author } \\
\text { (Reference) }\end{array}$ & $\begin{array}{l}\text { Year of } \\
\text { Publication }\end{array}$ \\
\hline \multirow{3}{*}{1.} & \multirow{3}{*}{$\begin{array}{l}\text { The study included } 3,432 \text { elderly patients }(53.9 \% \text { women, mean age at inclusion } 62.7 \pm 14.4 \\
\text { years) with an average follow-up time of } 11.3 \text { years. They observed a baseline increased serum } \\
\text { level of anti-HSV IgM antibodies associated with an increased risk of developing AD (Hazard ratio: } \\
1.96, p=0.012 \text { ). }\end{array}$} & $\begin{array}{l}\text { Harris et al. } \\
{[7]}\end{array}$ & 2015 \\
\hline & & $\begin{array}{l}\text { Devanand et } \\
\text { al. [17] }\end{array}$ & 2018 \\
\hline & & $\begin{array}{l}\text { LÖvheim et } \\
\text { al. [48] }\end{array}$ & 2014 \\
\hline \multirow{4}{*}{2.} & \multirow{4}{*}{$\begin{array}{l}\text { A population-based cohort study that followed } 512 \text { initially dementia-free older individuals for } 14 \\
\text { years. After controlling for age, gender, educational level, and APOE- } \varepsilon 4 \text { status, they found that } \\
\text { anti-HSV1 IgM antibody seropositivity was associated with a significantly increased risk of } \\
\text { developing AD (Hazard ratio: } 2.55 \text { ). * }\end{array}$} & $\begin{array}{l}\text { Mawanda et } \\
\text { al. [2] }\end{array}$ & 2013 \\
\hline & & $\begin{array}{l}\text { Harris et al. } \\
{[7,15]}\end{array}$ & 2015,2018 \\
\hline & & $\begin{array}{l}\text { Piacentini et } \\
\text { al. [11] }\end{array}$ & 2014 \\
\hline & & $\begin{array}{l}\text { Ball et al. } \\
\text { (Letenneur et } \\
\text { al.) [20] }\end{array}$ & 2012 \\
\hline 3. & $\begin{array}{l}\text { A prospective study performed on people over } 65 \text { years old for } 12 \text { years provided the most } \\
\text { persuasive evidence of an association between HSV1 infection and AD progression, considering } \\
\text { the presence of anti-HSV IgM antibodies as individuals with viral reactivation episodes. }\end{array}$ & $\begin{array}{l}\text { Acuña- } \\
\text { Hinrichsen et } \\
\text { al. (Letenneur } \\
\text { et al.) [31] }\end{array}$ & 2019 \\
\hline \multirow{3}{*}{4.} & \multirow{3}{*}{$\begin{array}{l}\text { In a study, a high level of HSV1 antibodies in patients with AD was found to correlate with cortical } \\
\text { atrophy of the gray matter using magnetic resonance. }\end{array}$} & $\begin{array}{l}\text { Agostini et al. } \\
\text { [3] }\end{array}$ & 2016 \\
\hline & & $\begin{array}{l}\text { Harris et al. } \\
{[7]}\end{array}$ & 2015 \\
\hline & & $\begin{array}{l}\text { Acuña- } \\
\text { Hinrichsen et } \\
\text { al. (Mancuso } \\
\text { et al.) [31] }\end{array}$ & 2019 \\
\hline \multirow[b]{2}{*}{5.} & \multirow[b]{2}{*}{$\begin{array}{l}\text { In a study, a high level of HSV1 antibodies in patients with AD was found to be correlated with } \\
\text { cognitive impairment evaluated through clinical tests that evaluate mental capacities (MMSE). }\end{array}$} & $\begin{array}{l}\text { Harris et al. } \\
{[7]}\end{array}$ & 2015 \\
\hline & & $\begin{array}{l}\text { Acuña- } \\
\text { Hinrichsen et } \\
\text { al. } \\
\text { (Kobayashi et } \\
\text { al.) [31] }\end{array}$ & 2019 \\
\hline
\end{tabular}

\section{TABLE 3: Serological studies demonstrating the relationship between HSV1 and AD}

* Among the 43 IgM-positive subjects, only two were IgG-negative, which supports recent HSV reactivation rather than primary infection as the cause of $A D$ in most IgM-positive subjects.

Key: HSV1 - Herpes simplex virus type-1, AD - Alzheimer's disease, Ig - Immunoglobulin

Anti-HSV avidity index can assess HSV1 reactivation, which occurs in prodromal AD and correlates with MCI symptoms $[3,7,11,17]$. Measuring HSV1 antibody avidity in serum, which is a simple, non-invasive test, could help with the disease prognosis [3]. Elevated HSV1 antibody titers equated with cortical bilateral temporal and orbitofrontal gray matter volume- an indicator of AD pathology [3,4,11]. Anti-HSV IgM levels correspond inversely with lower plasma amyloid- $\beta$ levels $[2,11]$. Lower amyloid- $\beta$ in plasma indicates increased amyloid deposition in the brain, a biomarker of $\mathrm{AD}[2,11]$.

The hypothesis that relates HSV1 to AD's pathogenesis has gained relevance because of the detection of viral DNA and viral proteins in the brains of AD cases. Additionally, serological studies show that HSV1 reactivation is associated with an increased risk of $\mathrm{AD}$. These studies prove that APOE- $\varepsilon 4$ is a multiplying 
factor that increases the risk of recurrence of HSV1, invasion of CNS by HSV1 on reactivation, and developing $\mathrm{AD}$ in general. Thus, if HSV1 and APOE- $\varepsilon 4$ are present together, the risk of acquiring AD increases exponentially.

\section{Herpes simplex encephalitis and Alzheimer's disease}

Another evidence that links HSV1 and Alzheimer's is the striking similarity between AD and HSE, a neurological condition caused by HSV1 (Figure 4).

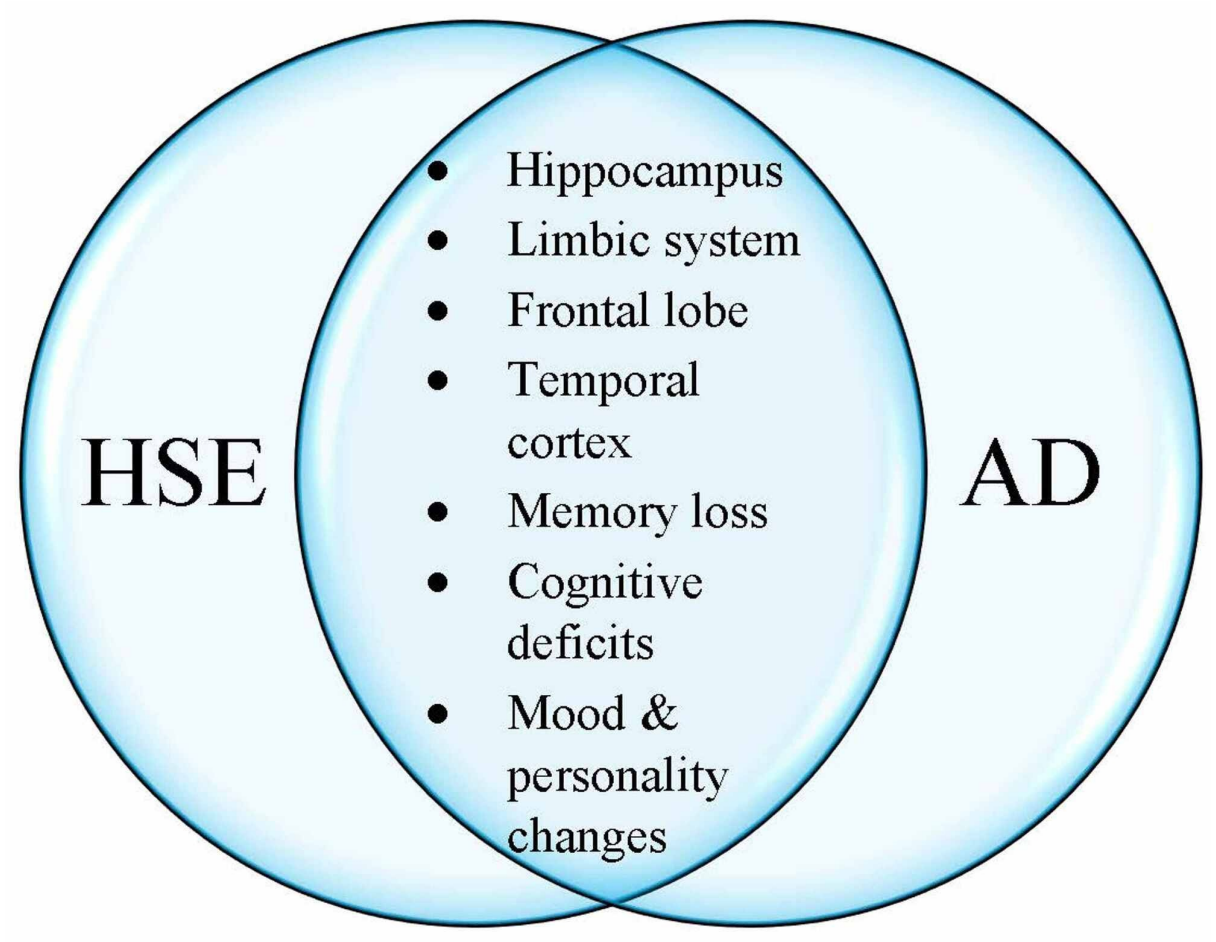

FIGURE 4: Herpes simplex encephalitis (HSE) affects the same anatomical locations in the brain, as involved in Alzheimer's disease (AD)

HSE patients are known to suffer long-term cognitive and behavioral symptoms similar to those seen in AD. HSE and AD patients have increased P-tau levels in cerebrospinal fluid (CSF).

Reference: $[4-5,7-8,11,14-17,19-20,27,30-31,44]$

\section{Effect of anti-viral treatment (AVT) on Alzheimer's disease}

Researchers observed that the production of P-tau depends directly on HSV1 replication or a protein depending on viral DNA replication $[8,20,22,27,46-47]$. In contrast, amyloid- $\beta$ production is dependent on viral spread only $[8,22,27,46]$. The drug inhibiting viral DNA replication (ultimately curtailing its spread) decreases P-tau production and amyloid- $\beta$ accumulation (Table 4) [47,49]. These drugs could impede brain degeneration and prove to be therapeutic for $\mathrm{AD}[4]$. 


\section{Cureus}

Sr.

No.

HSV1 infection and senile dementia (SD)

1.

Developing SD within 10 years of HSV diagnosis vs. HSV-negative subjects

2. Developing SD in AVT-treated HSV patients vs. untreated HSV patients

\begin{tabular}{|l|l|l|}
$\begin{array}{l}\text { Relative } \\
\text { risk }\end{array}$ & $\begin{array}{l}\text { Author } \\
\text { (Reference) }\end{array}$ & $\begin{array}{l}\text { Year of } \\
\text { Publication }\end{array}$ \\
\hline 2.564 & Itzhaki et al. [33] & 2018 \\
\hline 0.092 & Itzhaki et al. [33] & 2018 \\
\hline
\end{tabular}

TABLE 4: Relative risks for the development of senile dementia in HSV cases and after anti-viral treatment

Key: HSV1 - Herpes simplex virus type-1, SD - Senile dementia, AVT - Anti-viral treatment

Acyclovir, a nucleoside analog, targets infected cells and inhibits HSV1 replication and reactivation (Figure 5) $[7,11,27]$.

\begin{tabular}{|c|c|c|c|c|}
\hline Acyclovir & $\begin{array}{c}\text { Viral thymidine } \\
\text { kinase }\end{array}$ & $\begin{array}{l}\text { Acyclo-guanosine } \\
\text { monophosphate }\end{array}$ & Cellular kinases & $\begin{array}{l}\text { Acyclo-guanosine } \\
\text { triphosphate }\end{array}$ \\
\hline & & & & $\begin{array}{l}\text { Incorporated into } \\
\text { viral DNA resulting } \\
\text { in premature chain } \\
\text { termination }\end{array}$ \\
\hline
\end{tabular}

\section{FIGURE 5: Mechanism of action of acyclovir}

Reference: $[7,22,27]$

Valacyclovir is the bio-drug of acyclovir [7-8,17,22]. Figure 6 shows the mechanism of action of valacyclovir. Valacyclovir is rapidly hydrolyzed to acyclovir via the first-pass metabolism following oral administration [7]. The sustained activity of valacyclovir suggests that it may be symptomatic in the short-term and disease-modifying in the long-term, as per Devanand et al. [17]. They also mention a new trial of valacyclovir in the treatment of $\mathrm{AD}$ [17]. Penciclovir and foscarnet inhibit viral DNA replication [7].

\begin{tabular}{|c|c|c|c|c|}
\hline Valacyclovir & Viral thymidine & $\begin{array}{l}\text { Acyclo-guanosine } \\
\text { monophosphate }\end{array}$ & Cellular kinases & $\begin{array}{l}\text { Acyclo-guanosine } \\
\text { triphosphate }\end{array}$ \\
\hline & & $\begin{array}{l}\text { Incorporated into } \\
\text { viral DNA resulting } \\
\text { in premature chain } \\
\text { termination (PTC) }\end{array}$ & & $\begin{array}{l}\text { - Incorporated into } \\
\text { viral DNA } \\
\text { resulting in PTC } \\
\text { Inhibits viral DNA } \\
\text { polymerase } \\
\text { 100x higher } \\
\text { affinity to viral } \\
\text { than cellular } \\
\text { polymerase }\end{array}$ \\
\hline
\end{tabular}

FIGURE 6: Mechanism of action of valacyclovir

Reference: [17]

Table 5 displays certain advantages of acyclovir and valacyclovir. 


\section{Cureus}

\begin{tabular}{|c|c|c|c|c|}
\hline Sr. No. & Drug & Advantages & Author (Reference) & Year of Publication \\
\hline \multirow{5}{*}{1.} & \multirow{5}{*}{ Acyclovir } & Crosses blood-brain barrier (BBB) & Harris et al. [7] & 2015 \\
\hline & & \multirow{3}{*}{ Affects infected cells only } & Harris et al. [7] & 2015 \\
\hline & & & Itzhaki et al. [8] & 2012 \\
\hline & & & Piacentini et al. [11] & 2014 \\
\hline & & Safe for long term use & Harris et al. [7] & 2015 \\
\hline \multirow{12}{*}{2.} & \multirow{12}{*}{ Valacyclovir } & \multirow{2}{*}{ Crosses BBB after converting into acyclovir } & Harris et al. [7] & 2015 \\
\hline & & & Piacentini et al. [11] & 2014 \\
\hline & & \multirow{2}{*}{ Affects infected cells only } & Harris et al. [15] & 2018 \\
\hline & & & Devanand et al. [17] & 2018 \\
\hline & & \multirow{2}{*}{ Safe for long term use } & Harris et al. $[7,15]$ & 2015,2018 \\
\hline & & & Devanand et al. [17] & 2018 \\
\hline & & Inexpensive & Itzhaki et al. [8] & 2012 \\
\hline & & \multirow{3}{*}{ Better oral bioavailability } & Harris et al. [7] & 2015 \\
\hline & & & Itzhaki et al. $[8,22]$ & 2012,2014 \\
\hline & & & Piacentini et al. [11] & 2014 \\
\hline & & \multirow{2}{*}{ Low side-effect profile* } & Itzhaki et al. [8] & 2012 \\
\hline & & & Harris et al. [15] & 2018 \\
\hline
\end{tabular}

\section{TABLE 5: Advantages of acyclovir and valacyclovir}

${ }^{*}$ Renal problems and crystalluria have been reported as the only side-effects by ltzhaki et al. [8]

By preventing HSV1 spread and its replication, anti-viral agents would provide efficacious treatment (Table 6) [27]. A study by Lathe et al. demonstrated that treatment with AVT prevented almost $90 \%$ of cases from the development of AD [24]. While HSV1 is unlikely to be the sole cause of AD, an AVT must be evaluated, primarily due to the limited effects of existing treatments and the failure of new treatments tested in patients with $\mathrm{AD}$ within the last two decades [17]. A study by Lin et al. about a mixed glycoprotein HSV1 vaccine has proven valuable in reducing HSV1 in the mouse brain after peripheral infection $[7,15]$.

Intravenous immunoglobulin (IVIG) has shown anti-viral activity against HSV1 $[4,7,22,46]$. It neutralizes the extracellular virus $[7,22,46]$. Additionally, IVIG, in conjunction with lymphocytes, can destroy cells infected with HSV1 $[7,22,46]$. It prevents viral entry into cells and acts synergistically with acyclovir $[7,22,46]$. Thus, the combination of IVIG and acyclovir may be beneficial in treating $\mathrm{AD}[4,7,22,46]$. Another mechanism of action of IVIG is via anti- $\beta$-amyloid antibodies, which facilitates amyloid- $\beta$ clearance (Table 6 ) $[22,46]$. 


\section{Cureus}

\begin{tabular}{|c|c|c|c|c|}
\hline $\begin{array}{l}\text { Sr. } \\
\text { No. }\end{array}$ & Drug & Action on A-beta, P-tau, viral particles and dementia & $\begin{array}{l}\text { Author } \\
\text { (Reference) }\end{array}$ & $\begin{array}{l}\text { Year of } \\
\text { Publication }\end{array}$ \\
\hline \multirow{2}{*}{1.} & \multirow{2}{*}{$\begin{array}{l}\text { Acyclovir, penciclovir, } \\
\text { foscarnet }\end{array}$} & \multirow{2}{*}{ Decreases A-beta, P-tau, and viral particles } & $\begin{array}{l}\text { Devanand et } \\
\text { al. [17] }\end{array}$ & 2018 \\
\hline & & & $\begin{array}{l}\text { Itzhaki et al. } \\
\text { [22] }\end{array}$ & 2014 \\
\hline 2. & Acyclovir, valacyclovir & Decreases A-beta and P-tau & Harris et al. [7] & 2015 \\
\hline \multirow{5}{*}{3.} & \multirow{5}{*}{ Anti-herpetic drugs } & \multirow{5}{*}{ Decreased risk of dementia } & $\begin{array}{l}\text { Ezzat et al. } \\
\text { [21] }\end{array}$ & 2019 \\
\hline & & & $\begin{array}{l}\text { Lopatko et al. } \\
\text { [26] }\end{array}$ & 2019 \\
\hline & & & $\begin{array}{l}\text { Itzhaki et al. } \\
\text { [33] }\end{array}$ & 2018 \\
\hline & & & Eimer et al. & 2018 \\
\hline & & & $\begin{array}{l}\text { Rizzo et al. } \\
{[40]}\end{array}$ & 2020 \\
\hline 4. & Anti-viral drugs & Decreases A-beta, P-tau and slows or halts AD progression & $\begin{array}{l}\text { ltzhaki et al. } \\
{[32,49]}\end{array}$ & 2017,2016 \\
\hline \multirow{2}{*}{5.} & \multirow{2}{*}{ Acyclovir } & \multirow{2}{*}{ Decreases A-beta, P-tau, and viral particles } & $\begin{array}{l}\text { Itzhaki et al. } \\
\text { [8] }\end{array}$ & 2012 \\
\hline & & & $\begin{array}{l}\text { Piacentini et } \\
\text { al. [11] }\end{array}$ & 2014 \\
\hline \multirow{2}{*}{6.} & \multirow{2}{*}{ Penciclovir, foscarnet } & \multirow{2}{*}{ Decreases A-beta and P-tau } & Harris et al. $[7]$ & 2015 \\
\hline & & & $\begin{array}{l}\text { Wozniak et al. } \\
\text { [27] }\end{array}$ & 2011 \\
\hline 7. & Anti-viral drugs & $\begin{array}{l}\text { People treated with antiviral drugs are ten times less likely to } \\
\text { develop Alzheimer's disease* }\end{array}$ & $\begin{array}{l}\text { Makin et al. } \\
{[18]}\end{array}$ & 2018 \\
\hline \multirow{3}{*}{8.} & \multirow{3}{*}{$\begin{array}{l}\text { Intravenous } \\
\text { immunoglobulin (IVIG) }\end{array}$} & \multirow{3}{*}{ Decreases A-beta, P-tau, and viral particles } & $\begin{array}{l}\text { Agostini et al. } \\
{[4]}\end{array}$ & 2014 \\
\hline & & & Harris et al. [7] & 2015 \\
\hline & & & $\begin{array}{l}\text { Wozniak et al. } \\
\text { [46] }\end{array}$ & 2013 \\
\hline
\end{tabular}

\section{TABLE 6: Effect of anti-viral drugs and IVIG (intravenous Immunoglobulin)}

* Although neither study shows definitely that these viruses cause Alzheimer's disease, data from a population-wide health database in Taiwan have been used to suggest not only that HSV infection increases the risk of developing the condition, but also that people treated with antiviral drugs are 10 times less likely to develop Alzheimer's disease.

Itzhaki et al. and Wozniak et al. mention a drug, BAY57-1293, more efficient than acyclovir in inhibiting HSV1 replication and decreasing amyloid- $\beta$ and P-tau formation $[22,47]$. It also diminishes the size of cell clusters formed during infection much more efficiently than acyclovir, suggesting that BAY57-1293 is a more effective agent for treating $\mathrm{AD}[22,47]$.

Sulfated fucans from five algae with anti-viral activity (Scytothamnus australis, Marginariella boryana, Papenfussiella lutea, Splachnidium rugosum, and Undaria pinnatifida) has been studied [50]. Four sulfated 
fucan extracts prevented the accumulation of amyloid- $\beta$ and P-tau in HSV1-infected Vero cells $[3,50]$. The most active sulfated fucan combined with acyclovir was incredibly useful, so it may be suitable for further experimental testing to develop $\mathrm{AD}$ patients' treatment protocols to slow or stop disease progression [50].

The above data provide indirect evidence correlating HSV1 to AD; the similarities in the anatomical locations and the long-term symptoms seen in HSE cases and AD are too substantial to neglect. The studies demonstrating improvement in AD patients on anti-viral therapy further supports our theory that HSV1 is a potential etiological factor in $\mathrm{AD}$. Acyclovir and valacyclovir have proven to be the safest option amongst anti-herpetic drugs. The above studies have shown that substances with anti-viral properties are also useful in $\mathrm{AD}$. This additionally strengthens our hypothesis of viral infection being a causative factor in $\mathrm{AD}$. If future researchers can provide firm evidence associating the two, newer treatment and preventive alternatives can be developed, thereby enhancing the prognosis of $\mathrm{AD}$ and lowering the economic burden.

\section{Limitations}

The article is a narrative review, and it, therefore, does not follow the standard Preferred Reporting Items for Systematic Reviews and Meta-Analyses (PRISMA) guidelines for systematic reviews. The possibility of bias remains both within individual studies and across studies since we could not perform a full quality assessment. We were not able to access all the articles completely, so some omissions and oversimplifications are possible.

\section{Conclusions}

The deleterious consequences of HSV1 infection imitate the vital aspects of AD pathophysiology. Numerous studies have enlisted mechanisms used by HSV1 to prompt chief processes involved in the formation of unique signs of $\mathrm{AD}$, namely, amyloid plaques and neurofibrillary tangles. Co-localization of viral DNA with amyloid plaques, similarities in the anatomical locations involved, and serological studies linking the reactivation of the virus to AD signify HSV1 as one of the causative agents of AD. There is substantial evidence proving the efficacy of anti-viral agents in the treatment and deferral of AD. Further research establishing a causative link between HSV1 and AD are needed. Interventional clinical trials for a human HSV1 vaccine and a precise anti-viral regime for preventing and treating HSV1-infected MCI and AD patients are warranted. Until we establish new therapies, frequent screening and vaccination are vital in preventing the infection-related decline of cognition.

\section{Additional Information \\ Disclosures}

Conflicts of interest: In compliance with the ICMJE uniform disclosure form, all authors declare the following: Payment/services info: All authors have declared that no financial support was received from any organization for the submitted work. Financial relationships: All authors have declared that they have no financial relationships at present or within the previous three years with any organizations that might have an interest in the submitted work. Other relationships: All authors have declared that there are no other relationships or activities that could appear to have influenced the submitted work.

\section{References}

1. Mancuso R, Sicurella M, Agostini S, Marconi P, Clerici M: Herpes simplex virus type 1 and Alzheimer's disease: link and potential impact on treatment. Expert Rev Anti Infect Ther. 2019, 17:715-731. 10.1080/14787210.2019.1656064

2. Mawanda F, Wallace R: Can infections cause Alzheimer's disease?. Epidemiol Rev. 2013, 35:161-180. 10.1093/epirev/mxs007

3. Agostini S, Mancuso R, Baglio F, Clerici M: A protective role for herpes simplex virus type-1-specific humoral immunity in Alzheimer's disease. Expert Rev Anti Infect Ther. 2017, 15:89-91. 10.1080/14787210.2017.1264271

4. Agostini S, Clerici M, Mancuso R: How plausible is a link between HSV-1 infection and Alzheimer's disease? . Expert Rev Anti Infect Ther. 2014, 12:275-278. 10.1586/14787210.2014.887442

5. Olsson J, Lövheim H, Honkala E, Karhunen PJ, Elgh F, Kok EH: HSV presence in brains of individuals without dementia: the TASTY brain series. Dis Model Mech. 2016, 9:1349-1355. 10.1242/dmm.026674

6. Hu J, Liu CC, Chen XF, Zhang YW, Xu H, Bu G: Opposing effects of viral mediated brain expression of apolipoprotein E2 (apoE2) and apoE4 on apoE lipidation and A $\beta$ metabolism in apoE4-targeted replacement mice. Mol Neurodegener. 2015, 10:6. 10.1186/s13024-015-0001-3

7. Harris SA, Harris EA: Herpes simplex virus type 1 and other pathogens are key causative factors in sporadic Alzheimer's disease. J Alzheimers Dis. 2015, 48:319-353. 10.3233/JAD-142853

8. Itzhaki RF, Wozniak MA: Could antivirals be used to treat Alzheimer's disease? . Future Microbiol. 2012, 7:307-309. 10.2217/fmb.12.10

9. Alzheimer's disease. (2020). Accessed: September 20, 2020: https://www.cdc.gov/aging/aginginfo/alzheimers.htm.

10. Seeley WW, Miller BL: Alzheimer's disease. Harrison’s Principles of Internal Medicine. 20th Edition. McGraw-Hill Education, New York; 2018. 3108-3114.

11. Piacentini R, De Chiara G, Li Puma DD, et al.: HSV-1 and Alzheimer's disease: more than a hypothesis . Front Pharmacol. 2014, 5:97. 10.3389/fphar.2014.00097 
12. McNamara J, Murray TA: Connections between herpes simplex virus type 1 and Alzheimer's disease pathogenesis. Curr Alzheimer Res. 2016, 13:996-1005. 10.2174/1567205013666160314150136

13. Faldu KG, Shah JS, Patel SS: Anti-viral agents in neurodegenerative disorders: new paradigm for targeting Alzheimer's disease. Recent Pat Antiinfect Drug Discov. 2015, 10:76-83.

10.2174/1574891x10666150509193236

14. Martin C, Solís L, Concha MI, Otth C. : Herpes simplex virus tipo 1 como factor de riesgo asociado con la enfermedad de Alzheimer (Herpes simplex virus type 1 as risk factor associated to Alzheimer disease) [Article in Spanish]. Rev Med Chil. 2011, 139:779-786. 10.4067/S0034-98872011000600013

15. Harris SA, Harris EA: Molecular mechanisms for herpes simplex virus type 1 pathogenesis in Alzheimer's disease. Front Aging Neurosci. 2018, 2018:48. 10.3389/fnagi.2018.00048

16. De Chiara G, Marcocci ME, Civitelli L, et al.: APP processing induced by herpes simplex virus type 1 (HSV-1) yields several APP fragments in human and rat neuronal cells. PLoS One. 2010, 2010:13989. 10.1371/journal.pone.0013989

17. Devanand DP: Viral hypothesis and antiviral treatment in Alzheimer's disease . Curr Neurol Neurosci Rep. 2018, 18:55. 10.1007/s11910-018-0863-1

18. Makin S: The amyloid hypothesis on trial. As the development of treatments for Alzheimer's disease continues to stumble, is it time for researchers to broaden their list of the condition's potential causes?. Nature. 2018, 559:4-7. 10.1038/d41586-018-05719-4

19. Mangold CA, Szpara ML: Persistent infection with herpes simplex virus 1 and Alzheimer's disease-a call to study how variability in both virus and host may impact disease. Viruses. 2019, 11:966. 10.3390/v11100966

20. Ball MJ, Lukiw WJ, Kammerman EM, Hill JM: Intracerebral propagation of Alzheimer's disease: strengthening evidence of a herpes simplex virus etiology. Alzheimers Dement. 2013, 9:169-175. 10.1016/j.jalz.2012.07.005

21. Ezzat K, Pernemalm M, Pålsson S, et al.: The viral protein corona directs viral pathogenesis and amyloid aggregation. Nat Commun. 2019, 10:2331.

22. Itzhaki RF: Herpes simplex virus type 1 and Alzheimer's disease: increasing evidence for a major role of the virus. Front Aging Neurosci. 2014, 6:202. 10.3389/fnagi.2014.00202

23. Tudorache IF, Trusca VG, Gafencu AV: Apolipoprotein E - a multifunctional protein with implications in various pathologies as a result of its structural features. Comput Struct Biotechnol J. 2017, 15:359-365. 10.1016/j.csbj.2017.05.003

24. Lathe R, Tzeng NS, Itzhaki R: Herpes infections and dementia: rebutting alternative fact . Neurotherapeutics. 2019, 16:176-179. 10.1007/s13311-018-00700-5

25. Limongi D, Baldelli S: Redox imbalance and viral infections in neurodegenerative diseases. Oxid Med Cell Longev. 2016, 2016:6547248. 10.1155/2016/6547248

26. Lopatko Lindman K, Weidung B, Olsson J, et al.: A genetic signature including apolipoprotein Eع4 potentiates the risk of herpes simplex-associated Alzheimer's disease. Alzheimers Dement. 2019, 5:697-704. 10.1016/j.trci.2019.09.014

27. Wozniak MA, Frost AL, Preston CM, Itzhaki RF: Antivirals reduce the formation of key Alzheimer's disease molecules in cell cultures acutely infected with herpes simplex virus type 1. PLoS One. 2011, 6:25152. 10.1371/journal.pone.0025152

28. InformedHealth.org: Alzheimer's Disease: How Effective Are Cholinesterase Inhibitors? . Institute for Quality and Efficiency in Health Care, Cologne, Germany; 2006.

29. De Chiara G, Piacentini R, Fabiani M, et al.: Recurrent herpes simplex virus-1 infection induces hallmarks of neurodegeneration and cognitive deficits in mice. PLoS Pathog. 2019, 2019:1007617. 10.1371/journal.ppat.1007617

30. La Rosa F, Agostini S, Bianchi A, et al.: Herpes simplex virus-1 (HSV-1) infection induces a potent but ineffective IFN- $\lambda$ production in immune cells of AD and PD patients. J Transl Med. 2019, 17:286. 10.1186/s12967-019-2034-9

31. Acuña-Hinrichsen F, Muñoz M, Hott M, et al.: Herpes simplex virus type 1 enhances expression of the synaptic protein arc for its own benefit. Front Cell Neurosci. 2019, 12:505. 10.3389/fncel.2018.00505

32. Itzhaki RF: Herpes simplex virus type 1 and Alzheimer's disease: possible mechanisms and signposts . FASEB J. 2017, 31:3216-3226. 10.1096/fj.201700360

33. Itzhaki RF: Corroboration of a major role for herpes simplex virus type 1 in Alzheimer's disease . Front Aging Neurosci. 2018, 2018:324. 10.3389/fnagi.2018.00324

34. Bourgade K, Garneau H, Giroux G, et al.: $\beta$-Amyloid peptides display protective activity against the human Alzheimer's disease-associated herpes simplex virus-1. Biogerontology. 2015, 16:85-98. 10.1007/s10522014-9538-8

35. Steel AJ, Eslick GD: Herpes viruses increase the risk of Alzheimer's disease: a meta-analysis . J Alzheimers Dis. 2015, 47:351-364. 10.3233/JAD-140822

36. Epstein AL: Maladie d'Alzheimer, neuro-inflammation et virus herpétiques. Une piste qui trace son chemin (Alzheimer's disease, neuro-inflammation, and herpes viruses, a path that traces its way) [Article in French]. Med Sci. 2020, 36:479-486. 10.1051/medsci/2020090

37. Eimer WA, Vijaya Kumar DK, Navalpur Shanmugam NK, et al.: Alzheimer's disease-associated $\beta$-amyloid is rapidly seeded by Herpesviridae to protect against brain infection. Neuron. 2018, 99:56-63. 10.1016/j.neuron.2018.06.030

38. Piacentini R, Li Puma DD, Ripoli C, et al.: Herpes simplex virus type-1 infection induces synaptic dysfunction in cultured cortical neurons via GSK-3 activation and intraneuronal amyloid- $\beta$ protein accumulation. Sci Rep. 2015, 5:15444. 10.1038/srep15444

39. Civitelli L, Marcocci ME, Celestino I, et al.: Herpes simplex virus type 1 infection in neurons leads to production and nuclear localization of APP intracellular domain (AICD): implications for Alzheimer's disease pathogenesis. J Neurovirol. 2015, 21:480-490. 10.1007/s13365-015-0344-0

40. Rizzo R: Controversial role of herpesviruses in Alzheimer's disease . PLoS Pathog. 2020, 2020:1008575. 10.1371/journal.ppat.1008575

41. McManus RM, Heneka MT: Role of neuroinflammation in neurodegeneration: new insights . Alzheimers Res 


\section{Cureus}

Ther. 2017, 9:14. 10.1186/s13195-017-0241-2

42. Santana S, Sastre I, Recuero M, Bullido MJ, Aldudo J: Oxidative stress enhances neurodegeneration markers induced by herpes simplex virus type 1 infection in human neuroblastoma cells. PLoS One. 2013, 2013:75842. 10.1371/journal.pone.0075842

43. Carter CJ: APP, APOE, complement receptor 1, clusterin and PICALM and their involvement in the herpes simplex life cycle. Neurosci Lett. 2010, 483:96-100. 10.1016/j.neulet.2010.07.066

44. Bourgade K, Dupuis G, Frost EH, Fülöp T: Anti-viral properties of amyloid- $\beta$ peptides. J Alzheimers Dis. 2016, 54:859-878. 10.3233/JAD-160517

45. Lövheim H, Gilthorpe J, Johansson A, Eriksson S, Hallmans G, Elgh F: Herpes simplex infection and the risk of Alzheimer's disease: A nested case-control study. Alzheimers Dement. 2015, 11:587-592.

10.1016/j.jalz.2014.07.157

46. Wozniak MA, Itzhaki RF: Intravenous immunoglobulin reduces $\beta$ amyloid and abnormal tau formation caused by herpes simplex virus type 1. J Neuroimmunol. 2013, 257:7-12. 10.1016/j.jneuroim.2013.01.005

47. Wozniak MA, Frost AL, Itzhaki RF: The helicase-primase inhibitor BAY 57-1293 reduces the Alzheimer's disease-related molecules induced by herpes simplex virus type 1. Antiviral Res. 2013, 99:401-404. 10.1016/j.antiviral.2013.07.003

48. Lövheim H, Gilthorpe J, Adolfsson R, Nilsson LG, Elgh F: Reactivated herpes simplex infection increases the risk of Alzheimer's disease. Alzheimers Dement. 2015, 11:593-599. 10.1016/j.jalz.2014.04.522

49. Itzhaki RF: Herpes and Alzheimer's disease: subversion in the central nervous system and how it might be halted. J Alzheimers Dis. 2016, 54:1273-1281. 10.3233/JAD-160607

50. Wozniak M, Bell T, Dénes Á, Falshaw R, Itzhaki R: Anti-HSV1 activity of brown algal polysaccharides and possible relevance to the treatment of Alzheimer's disease. Int J Biol Macromol. 2015, 74:530-540. 10.1016/j.ijbiomac.2015.01.003 